\title{
REVOLUSI GURU DALAM PEMBELAJARAN ABAD 21
}

\author{
Agus Budi Hariyanto ${ }^{1}$, Ukhti Raudhatul Jannah ${ }^{2}$ \\ MTsN Sumber Bungur Pamekasan \\ Pendidikan Matematika, FKIP, Universitas Madura \\ Email: agusbudihariyanto@gmail.com
}

\begin{abstract}
Abstrak:
Tujuan penulisan ini adalah untuk mendeskripsikan berbagai bentuk tugas baru guru di abad yang serba canggih dan bagaimana guru harus dapat bertransformasi mengikuti perkembangan zaman. Data diperoleh dari observasi dan dokumentasi dari sumber pustaka.Inductive analysis technique digumakam umtuk menganalisi data. Hasil analisis data menunjukkan bahwa guru bukan hanya berpearan sebagai motivator tetapi juga sebagai fasilitator yang membantu dan memfasilitasi siswa mencari informasi dari berbagai sumber yang beragam melalui tekhnologi.
\end{abstract}

Kata Kunci: Pembelajaran, Revolusi guru, Era digital

\section{Pendahuluan}

Berdasarkan Undang-Undang

Nomor 14 Tahun 2005 tentang Guru dan Dosen, disebutkan bahwa guru adalah pendidik profesional dengan tugas utama mendidik, mengajar, membimbing, mengarahkan, melatih, menilai, dan mengevaluasi peserta didik pada pendidikan anak usia dini jalur pendidikan formal, pendidikan dasar, dan pendidikan menengah. Uno (2009) menyatakan bahwa guru adalah orang yang memiliki kemampuan merancang program pembelajaran serta mampu menata dan mengelola kelas agar peserta didik dapat belajar dan pada akhirnya dapat mencapai tingkat kedewasaan sebagai tujuan akhir dari proses pendidikan.Secara konseptual guru sebagai tenaga profesional harus memenuhi berbagai persyaratan kompetensi untuk menjalankan tugas dan kewenangannya secara profesional (Aprillinda, 2019).

$\begin{array}{ccr}\text { Adapun } & \text { perjalanan } & \text { sejarah } \\ \text { pendidikan di } & \text { Indonesia } & \text { memiliki }\end{array}$
perkembangan yang sangat dinamis. Perubahan kurikulum seringkali dilakukan dengan tujuan untuk meningkatkan daya saing sumber daya manusia didunia internasional. Sejalan dengan perubahan kurikulum, berbagai desain tekhnik, strategi dan metode pembelajaran juga mengalami perkembangan. Profesi guru merupakan profesi tumpuan harapan banyak pihak guna mengatasi perubahan di masyarakat saat ini yang begitu cepat dan pesat (Setiawan, 2017).

Memasuki abad 21 terjadi pergeseran yang sangat luar biasa. Sebuah abad yang sangat berbeda dari abad-abad sebelumnya. Ilmu pengetahuan disegala bidang berkembang pesat terutama pada bidang Information Communication and Technology (ICT) yang serba canggih menjadikan dunia terasa semakin tanpa batas. ICT yang berarti TIK(Teknologi Informasi dan Komunikasi) mencakup dua aspek, yaitu Teknologi Informasi dan Teknologi Komunikasi. Teknologi Informasi meliputi segala hal yang berkaitan dengan proses, penggunaan sebagai alat bantu, manipulasi, dan pengelolaan informasi. Teknologi komunikasi mencakup segala hal yang berkaitan dengan penggunaan alat bantu untuk memproses dan mentrasfer data dari perangkat yang satu ke lainnya. Karena itu, penguasaan TIK berarti kemampuan memahami dan menggunakan alat TIK secara umum termasuk komputer (Computer literate) dan memahami informasi (Information literate). Tinio dalam Rahim (2011) mendefenisikan TIK sebagai seperangkat alat yang digunakan untuk berkomunikasi dan menciptakan, mendiseminasikan, menyimpan, dan mengelola informasi. Teknologi yang dimaksud termasuk komputer, internet, teknologi penyiaran (radio dan televisi), dan telepon. Definisi umum TIK adalah computer, internet, telepon, televisi, radio, 
dan peralatan audiovisual (Rahim, 2011). Canggihnya ICT memudahkan pencarian dan penyampaian informasi dari berbagai belahan dunia yang bisa diakses oleh siapapun, dimanapun,kapanpun tanpa dibatasi oleh ruang dan waktu dengan sangat mudah.

Hal ini juga berdampak pada kehidupan sosial. Secara umum kehidupan sosial budaya masyarakat turut mengalami pergeseran, pada abad ini telah terjadi pergeseran karakter masyarakat secara fundamental yang sangat berpengaruh terhadap tuntutan perubahan karakteristik guru pada abad 21. Bentuk sederhana yang bisa kita lihat dalam kehidupan sehari-hari adalah tingkat ketergantungan mereka terhadap alat komunikasi berupa handphone (android). Mereka tidak bisa lepas pada produk ini dengan segala kecanggihan fitur dan aplikasi didalamnya kemanapun dan dimanapun mereka pergi. Ini membuktikan bahwa kecanggihan tekhnologi (ICT) telah mampu merubah sikap dan perilaku kehidupan masyarakat. Bagaimana peran guru menghadapi fenomena yang terjadi? Tentunya guru sebagai bagian pelayan pendidikan bagi masyarakat (termasuk siswa) harus bisa bertransformasi dalam bentuk tekhnik berupa layanan proses pembelajaran dan bertransformasi secara sosial budaya dalam lingkungan bermasyarakat.

Oleh karena itu, menurut Aprillinda (2019), pada era ini guru seharusnya benarbenar menjadi guru yang profesional, agar mampu menghadapi tantangan. Untuk itu, kompetensi kepribadian, kompetensi profesional, dan kompetensi sosial, serta kompetensi pedagogik seorang guru perlu dikembangkan sehingga mampu mendidik siswa yang mempunyai kemampuan memprediksi dan menanggulangi. Di sisi lain, tugas-tugas guru yang bersifat profesional harus ditunjang oleh sistem penghargaan yang sesuai, sehingga guru mampu memfokuskan diri pada peningkatan kualitas layanan yang diberikan. Hal ini sejalan dengan kriteria pekerjaan profesional yang menyebutkan bahwa guru berhak mendapat imbalan yang layak, bukan hanya dalam bentuk materi, tetapi juga dalam bentuk penghargaan, hormat, dan rasa segan masyarakat terhadap guru.Guru ditantang untuk melakukan akselerasi terhadap perkembangan informasi dan komunikasi. Pembelajaran di kelas dan pengelolaan kelas, pada abad ini harus disesuaikan dengan standar kemajuan teknologi informasi dan komunikasi.

\section{Metode}

Artikel ini merupakan studi literatur yang dikaji dari berbagai sumber buku dan artikel tentang revolusi guru dalam pembelajaran abad 21 yang dikaitkan dengan fenomena yang terjadi saat ini pada proses pembelajaran.

Data dalam artikel ini adalah kata, klausa, dan kalimat yang diperoleh dari sumber pustaka. Menurut Zed (2014), studi pustaka (library research), penelusuran pustaka tidak hanya untuk langkah awal menyiapkan kerangka penelitian (research design) akan tetapi sekaligus memanfaatkan sumber-sumber perpustakaan untuk memperoleh data. Observasi dan dokumentasi digunakan sebagai metode dalam pengumpulan data, kemudian dilanjutkan dengan reduksi, ferivikasi, dan analisis data.

\section{Hasil dan Pembahasan}

Berbicara guru, tentunya tidak akan pernah habis untuk senantiasa dibahas. Dengan segala dinamika perkembangan sejarahnya, guru memiliki peran yang sangat vital dalam pembangunan sebuah bangsa. Dimasa lalu guru mendapat gelar pahlawan tanda jasa, karena perjuangan dan loyalitasnya dalam mendidik siswanya. Kemudian pada tahun 2005, muncul program sertifikasi guru yang digulirkan oleh pemerintah membuat guru di Indonesia berlomba-lomba untuk mendapatkan predikat guru profesional yang notabene berhubungan dengan tunjangan profesi yang menjanjikan dari sisi kesejahteraan guru. Paradigma gurupun berubah. Terlepas dari perdebatan tunjangan profesi guru, merupakan sebuah kewajaran jika pemerintah memberikan perhatian khusus kepada guru, mengingat pentingnya peranan guru dalam membangun peradaban. 
Terdapat sebuah anekdot yang membandingkan tanggung jawab seorang dokter dan seorang guru dalam menjalankan profesinya. Dokter bertanggung jawab untuk membantu pasiennya sembuh dari penyakitnya, dan guru bertanggung jawab untuk membantu siswanya memahami pelajaran yang dipelajari. Namun apabila keduanya melakukan kesalahan dalam penanganan, maka dampaknya akan berbeda. Sebagai contoh seorang dokter melakukan kesalahan dalam mendiagnosa pengobatan penyakit seorang pasiennya, maka yang akan menjadi korban adalah satu orang pasien yang ia tangani. Beda halnya dengan guru, jika dia melakukan kesalahan mengajar didalam kelas dengan jumlah siswa 32 orang, maka 32 orang siswa yang akan mengalami pembodohan. Bagaimana jika seorang guru mengajar lebih dari satu kelas? Bagaimana jika yang melakukan kesalahan dalam mengajar tidak hanya satu orang guru? Maka akan terjadi, hancurlah peradaban sebuah bangsa.

Guru-gurupun semakin dituntut untuk terus bisa beradaptasi dengan tuntutan perkembangan kurikulum pada jamannya. Sebagai garda terdepan dalam dunia pendidikan, guru tentu telah mendapat perlakuan berupa pendidikan dan pelatihan dari berbagai pihak baik pemerintah ataupun lembaga swasta (dalam ataupun luar negeri) yang peduli terhadap dunia pendidikan untuk meningkatkan kompetensi dan kualitas guru.

Berbagai perubahan juga sangat dirasakan dalam dunia pendidikan. Tuntutan perubahan layanan pendidikan menjadi sebuah keniscayaan. Tantangan bagi guru semakin kompleks dibandingkan pada era sebelumnya. Guru dihadapkan dengan siswa yang bervariatif (dari berbagai aspek), peningkatan kuantitas dan kualitas materi yang sigifikan, peningkatan standar proses pembelajaran yang kekinian serta tuntutan kemampuan berpikir siswa yang semakin kritis yang berujung pada tuntutan perubahan pola pikir, perilaku mengajar dan revolusi guru dalam pembelajaran.Pendidikan dalam era ini harus mampu mempersiapkan peserta didiknya dalam menghadapi tiga hal, antara lain : (1) mempersiapkan anak untuk dapat menyelesaikan masalah, yang masalahnya saat ini belum muncul, (2) mempersiapkan anak untuk dapat bekerja, yang jenis pekerjaannya saat ini belum ada dan (3) mempersiapkan anak untuk dapat menggunakan teknologi yang sekarang teknologinya belum ditemukan. Untuk bisa menghadapi tantangan tersebut, syarat penting yang harus dipenuhi adalah bagaimana menghasilkan guru yang berkualitas dan kompeten (Fadel, 2015).

Dalam sebuah ungkapan disebutkan "Buku bisa digantikan tekhnologi, tetapi peran guru tidak bisa digantikan, bahkan diperkuat, guru harus bisa memanfaatkan tekhnologi digital untuk mendesain pembelajaran yang kreatif". Jika kita telaah ungkapan tersebut bisa dimaknai bahwa buku bisa digantikan dengan tekhnologi, artinya internet sudah menyediakan semua kebutuhan informasi tentang materi sedang dan akan yang dipelajari oleh siswa, akan tetapi peran guru tidak bisa digantikan. Disinilah guru berperan sebagai motivator dan fasilitator, yaitu membantu dan memfasilitasi siswanya mencari informasi dari berbagai sumber yang lebih beragam. Dalam proses memotivasi dan memfasilitasi, guru adalah mitra belajar siswa (Student center) dan bukan lagi sebagai sumber pengetahuan (Teacher center). Ini artinya seorang guru dituntut untuk menyiapkan diri sebelum proses pembelajaran, seperti sumber informasi yang dibutuhkan siswa secara beragam untuk mempermudah dan mempercepat pencarian informasi melalui jaringan internet.

Dari pembahasan singkat diatas penulis mencoba menarik beberapa bagian penting hal yang harus dilakukan oleh guru sebagai bentuk revolusi guru dalam pembelajaran abad 21:

1. Guru sebagai Motivator dan Fasilitator dalam Pembelajaran

Pendidikan di Indonesia tidak lebih dari guru berbicara dan siswa mendengarkan. Jadi, hasil belajar adalah apa yang disampaikan guru dikurangi apa yang lupa (bisa dipastikan siswa lupa semua) (Wenger, 2002). Pada sisi lain disebutkan bahwa 
pendidikan yang dikembangkan di Indonesia adalah pendidikan tidak lain seperti pendidikan "gaya Bank". Model ini menurut pengamatan Freire (1984), menjadi sebuah kegiatan menabung. Dimana siswa menjadi celengan sedangkan guru sebagai penabungnya. Ruang gerak yang disediakan hanya sebatas penerima, mencatat dan menyimpan. Semakin banyak siswa menyimpan tabungan, semakin kurang mengembangkan kesadaran kritisnya. Guru menjadi super power dalam konteks guru sebagai subjek dan siswa sebagai objek, guru yang "menakdirkan" sedangkan siswa "ditakdirkan". Dari uraian tersebut, maka dipandang perlu sebuah revolusi pembelajaran mengingat Paradigma pembelajaran semacam ini merupakan paradigma keliru yang menyebabkan tidak maksimalnya hasil belajar yang dicapai siswa. Padahal jika kita sadari bersama, manusia adalah makhluk yang unik. Ia bisa belajar melalui pendengaran, penglihatan, pengecapan, sentuhan, penciuman, penghayalan (imajinasi), intuisi, dan perasaan (Mahfudz, 2011).

Terdapat beberapa langkah yang bisa dilakukan oleh guru dalam memposisikan dirinya sebagai motivator dan fasilitator dalam desain pembelajaran abad 21.

1) Menciptakan jalinan kemitraan dengan siswa (partnership)

Pembelajaran dengan model student center adalah sebuah model belajar yang bisa mengakomodir berbagai tuntutan pembelajaran abad 21. Siswa mendapatkan kemerdekaan belajar dan guru tidak lagi sebagai satusatunya sumber pengetahuan. Guru abad 21 adalah guru yang mampu menciptakan hubungan erat dengan siswanya, harus menempatkan dirinya sebagai mitra dalam belajar.

Jika kita belajar dari sejarah Nabi Muhammad SAW, mengapa semua orang yang bersama-sama dan mendampingi beliau dalam berjuang disebut sahabat, padahal mereka adalah murid-muridnya? Panggilan sahabat oleh Nabi Muhammad SAW bukanlah sekedar membedakan antara Nabi Muhammad SAW dengan muridnya, tetapi menyadari bahwa sahabat merupakan sumber dan aset berharga dalam menyukseskan perjuangan baginda Rasulullah Muhammad SAW. Demikian halnya guru, sudah saatnya guru belajar dari baginda Rasulullah Muhammad SAW yaitu siswa memiliki peranan penting dalam suksesnya belajar mengajar didalam ataupun diluar kelas.

2) Menjadi guru gaul (slang teacher) sebagai guru harus menyadari bahwa hidup adalah keniscayaan dengan masa depan yang penuh perubahan. Dunia siswa kita sangat berbeda dengan yang pernah ada (sekarang dikenal sebagai generasi Z). Perbedaan karakteristikyang signifikan antar generasi $\mathrm{Z}$ dengan generasi lainadalah penguasaan informasi dan teknologi (Putra, 2016). Bagi generasi $\mathrm{Z}$ informasi dan teknologi adalah hal yang sudah menjadi bagian dari kehidupan mereka, karena mereka lahir dimana akses terhadap informasi, khususnya internet sudah menjadi budaya global, sehingga hal tersebut berpengaruh terhadap nilai - nilai, pandangan dan tujuan hidup mereka.Masa depan mereka juga sangat bergantung pada kemapuan mereka menyerap berbagai berbagai konsep baru dan terbarukan, menentukan berbagai pilihan baru, dan belajar serta beradaptasi sepanjang hayat.

Kondisi saat ini sangat berbeda dengan dunia kita sekolah dahulu, mau tidak mau, siap tidak siap, sebagai guru harus bisa menghadapi model tantangan pembelajaran abad 21. Menjadi guru harus gaul dalam mengikuti 
perkembangan informasi apa yang paling berpengaruh dalam kehidupan dunia belajar siswanya. Guru harus memiliki kemampuan mengakses informasi baik lewat media massa ataupun daring yang dimiliki guru, karena kecepatan siswa dalam mengakses informasi melebihi kecepatan akses informasi gurunya. Berikut beberapa langkah yang bisa dilakukan untuk menjadi guru gaul: (1)ikutilah perkembangan siswa dari semua aspek kehidupan siswa (musik, mode, olahraga, dll), (2) kenalilah kehidupan siswa, (3) masuklah dalam kehidupan mereka, (4), mengajarlah sesuai gaya belajar yang sangat mereka sukai.

3) Selalu positive thinking

Dalam proses pendidikan membutuhkan keberadaan guru yang bisa menerima keberadaan siswanya dalam kondisi apapun. Seorang guru harus mampu menciptakan hubungan saling percaya dan nyaman serta membangun hubungan komunikasi yang memberdayakan siswa hingga tahap mampu mengaktualisasikan dirinya. Proses pembelajaran yang baik adalah proses yang mengundang siswa untuk melihat dirinya sebagai manusia yang mampu dan bernilai, mengarahkan diri sendiri, memotivasi mereka untuk berbuat sesuai dengan keyakinan mereka dengan tanggung jawab. Oleh karena itu, yang dapat menilai bahwa pembelajaran telah terorganisasikan dengan baik (Yusuf, 2018) adalah teman sejawat, kepala sekolah dan peserta didik. Para peserta didik seringkali mempunyai posisi terbaik dalam melakulan penilaian.

4) Mengajar dengan cara kerja otak (Working Principle Of The Brain) Otak manusia ibarat sebuah harddisk dengan mekanisme tertentu dalam mengakses dan menyerap informasi. Seorang guru harus memahami bagaimana meningkatkan cara kerja otak siswanya dalam pembelajaran, mengingat salah satu bagian penting dalam pembelajaran adalah pembelajaran berbasis cara kerja otak. Proses Pembelajaran yang memaksimalkan cara kerja otak berarti tidak hanya memberdayakan satu belahannya saja tetapi mengupayakan fungsi keduanya secara seimbang (Munawaroh, 2005). Sehingga menghasilkan siswa yang tidak hanya mampu berfikir secara berurutan dan terstruktur tetapi mampu berfikir divergen,global dan kreatif. Salah satu upaya untuk memaksimalkan fungsi otak dalam proses pembelajaran adalah dengan merancang metode belajar. Ciptakan suasana belajar yang menyenangkan, implementasinya sangat bergantung pada bagaimana kemampuan seorang guru dalam mengelola pembelajaran bergantung kondisi kelasnya.

5) Layani setiap perbedaan individu (Individual Difference)

Kemampuan seseorang untuk menyerap dan memahami sebuah mata pelajaran sudah pasti berbeda. Ada yang cepat, danada pula yang sangat lambat. Karenanya dalam penyerapan informasi terkadang setiap individu siswa memiliki cara yang berbeda pula.

Terdapat beberapa gaya belajar siswa yang sering kita temukan, walaupun secara sadar kita sering mengabaikannya. Sudah saatnya sebagai guru abad 21 bisa memahami bagaimana gaya belajar setiap individu siswanya, dan bagaimana cara kita memberikan layanan belajarnya.

6) Menumbuhkan kepercayaan diri (Confidence)

Sebagai motivator, guru harus selalu terbuka kepada siswanya, jangan pernah segan memberikan 
pujian terhadap siswa yang telah melakukan aktivitas dan hasil positif dalam bentuk verbal, perbuatan atau cukup perhatian yang mendalam, karena siswa juga manusia yang selalu ingin dihargai.

7) Menciptakan lingkungan belajar menyenangkan (enjoyfull learning) Selama ini masih banyak guru yang lebih fokus terhadap apa yang akan diajarkannya, dengan mengabaikan bagaimana kondisi lingkungan belajar siswanya. Menata kelas tidak hanya menambahkan berbagai assesoris yang menarik dan nyaman dipandang, tetapi bagaimana mampu menata kelas dengan mengajarkan dan mengontrol karakter yang baik.

2. Guru Harus Memiliki Minat Baca yang Tinggi

Pada kegiatan budaya membaca dibeberapa madrasah/sekolah nampak bahwa disaat siswa melakukan aktivitas membaca bersama, guru tidak ikut serta membaca. Indikator ini menunjukkan bahwa minat membaca guru lebih rendah dibandingkan siswanya. Indikator lain bisa dilihat dari kepemilikan buku yang masih kurang. Padahal, guru pasti memiliki permasalahan dalam pembelajarannya. Hal ini perlu dicarikan pemecahan dengan cara menambah pengetahuan melalui membaca baik dalam bentuk buku maupun digital melalui fasilitas internet.

Tanpa memiliki minat baca yang tinggi seorang guru akan ketinggalan pengetahuan dibandingkan siswanya.Hal ini akan berakibat menurunnya rasa kepercyaan seorang siswa terhadap gurunya, bahkan akan berakibat terhadap proses pembelajaran.

3. Guru Harus Memiliki Kemampuan Menulis

Menulis sebenarnya adalah bagian akibat dari tingginya minat seseorang dalam membaca. Menurut Farida (dalam Muharani, 2018), membaca pada hakikatnya adalah suatu hal yang rumit yang melibatkan banyak hal, tidak hanya sekedar melafalkan tulisan, tetapi juga melibatkan aktivitas visual, berpikir, psikolinguistik, dan metakognitif. Keterampilan dalam menulis memang perlu proses melalui latihan. Melalui tulisan seorang guru bisa memunculkan ide dan gagasan inovatif baik dalm bentuk buku ataupun karya tulis ilmiah. Kemampuan menulis seorang guru akan meningkatkan rasa percaya diri dihadapan siswa dan bisa menimbulkan keseganan siswa terhadap guru yang bersangkutan.

Kaitannya dengan era digital, guru yang memiliki kemampuan menulis tidak hanya bisa mengunduh/mendownload file dari internet tapi juga bisa mengunggah karya tulis sebagai bagian kontribusinya dalam mengembangkan kualitas pembelajaran.

4. Guru Harus Kreatif dan Inovatif Dalam proses pembelajaran seorang guru harus mampu menguasai berbagai tekhnik dan metode belajar dengan mengkombinasikan pembelajaran berbasis digital dengan pembelajaran langsung (tatap muka) dikelas atau lebih dikenal dengan pembelajaran berbasis e learning (digital learning). Ada banyak pilihan pembelajaran berbasis e learning yang bisa dipakai dalam misalnya Blended Learning, Hybrid Learning, Schoology, dll. Digital learning untuk meningkatkan pengalaman belajar siswa dan keterlibatan siswa yang lebih mendalam dalam belajar untuk mencapai higher order thinking skills dan untuk mengoptimalkan hasil pembelajaran serta menjamin desain pembelajaran yang berkualitas tinggi (Ifenthaler, dkk).

Dengan keberadaan e learning seorang guru pada abad 21 dituntut untuk memiliki kemampuan menerapkan multimedia serta mampu kreatif dan inovatif dalam memanfaatkan media baru (New Media) dalam bentuk web.

5. Guru Harus Mau Menerima Perubahan 
Selama ini sebagian besar guru sudah merasa nyaman denganapa yang sudah ia lakukan saat ini dan cenderung menutup diri terhadap perubahan. Desain pembelajaran abad 21 yang berbasis Information Communication and Technology (ICT) merupakan hal baru dalam sudut pandang guru yang belum termotivasi untuk menerima perubahan. Guru harus memiliki keyakinan melakukan proses penyesuaian diri terhadap perubahan. Untuk itu, di abad 21 ini guru dan siswa harus lebih produktif untuk kemajuan ICT dan aksesnya di dalam pembelajaran (Awwal, dkk. 2016).

\section{Simpulan dan Saran}

Di era ICT ini, guru dituntut untuk memiliki complex ability, kemampuan pemanfaatan Information Communication and Technology (ICT) dalam mendesain pembelajarannya walaupun kemampuan ini merupakan keterampilan yang perlu dilatih secara berkelanjutan. Pengembangan alat evaluasi pembelajaran dengan memanfaatkan ICT dirasa mampu menekan kelemahan sistem konvensional saat ini (Rahayu, 2018). Tugas guru tidaklah mudah untuk dilakukan, perlu usaha dan kesiapan mental emosional yang luar biasa. Menjadi guru bukanlah sebatas pekerjaan belaka, tetapi panggilan jiwa untuk bersumbangsih membangun anak bangsa agar lebih maju dan berdaya. Menjadi guru haruslah menjadi piihan dan keterpanggilan, bukan merupakan keterpaksaan, bukan merupakan opsi kedua atas pekerjaan-pekerjaan yang lain, apalagi daripada tidak memiliki pekerjaan.

\section{Daftar Pustaka}

Aprillinda, M. 2019. Perkembangan Guru Profesional di Era Revolusi Industri 4.0. Prosiding Seminar Nasional Pendidikan Program Pascasarjana Universitas PGRI Palembang. 12 Januari 2019. 600-608.

Awwal, N., Scoular, C., \& Care, E. (2016, October). The Capacity of Games to Assess 21st Century Skills in Multiple Collaborative Environments. In 10th
European Conference on Games Based Learning: ECGBL 2016 (p. 27). Academic Conferences and publishing limited.

Fadel, M.B. 2015. Skills for the 21st Century: What Should Students Learn?. Massachusetts: Center for Curriculum Redesign Boston.

Freire, P. 1984. Pendidikan Sebagai Praktek Pembebasan. Jakarta: Gramedia.

Ifenthaler, D., Adcock, A. B., Erlandson, B. E., Gosper, M., Greiff, S., \& PirnayDummer, P. (2014). Challenges for education in a connected world: Digital learning, data rich environments, and computer-based assessment-Introduction to the inaugural special issue of technology, knowledge and learning. Technology, knowledge and learning, 19(1-2), 121-126.

Muharani, S. 2018. Upaya Guru dalam Menumbuhkan Minat Baca Siswa Sekolah Dasar. FKIP Universitas Negeri Jambi.

Mahfudz, A. 2011. Be a Good Teacher or Never: 9 Jutsu Cepat Menjadi Guru Profesional Berkarakter Trainer. Bandung: Nuansa.

Munawaroh, dkk. 2005. Neuroscience dalam Pembelajaran. Majalah Ilmiah Pembelajaran. Vol. 1, No. 1. 121.

Putra, Y.S. 2016. The Oritical Review. Teori Perbedaan Generasi. Among Makarti. Vol. 9, No. 18. 123-132.

Rahayu, E.E., Listiyadi, A. 2018. Pengembangan Alat Evaluasi Pembelajaran Berbasis Information and Communication Technologies (ICT) pada Materi Mengelola Dokumen Transaksi. Universitas Negeri Surabaya. 1-7.

Rahim, H.M.Y., 2011. Pemanfaatan Ict Sebagai Media Pembelajaran dan 
Informasi pada UIN Alauddin Makassar. Sulesana.Vol, 6. No 2. 127-135.

Setiawan, D., J. Sitorus. 2017. Urgensi Tuntutan Profesionalisme dan Harapan Menjadi Guru Berkarakter (Studi Kasus: Sekolah Dasar dan Sekolah Menengah Pertama di Kabupaten Batubara). Cakrawala Pendidikan. Vol 1, No. 1. 122-129.

Undang-undang Republik Indonesia No 14 Tahun 2005 tentang Guru dan Dosen.

Uno, H.B. 2009. Profesi Kependidikan: Problema, Solusi, dan Reformasi
Pendidikan di Indonesia. Jakarta: Bumi Aksara.

Wenger, W. 2002. The Einstein Factor. Simon \& Schuster Audio/Nightin. North Miami.

Yusuf, B.B. 2018. Konsep dan Indikator Pembelajaran Efektif. Jurnal Kajian Pembelajaran dan Keilmuan. Vol. 1, No. 2. 17.

Zed, M. 2014. Metode Penelitian Kepustakaan. Jakarta: Yayasan Obor Indonesia. 